\title{
REGULATION OF QUALITY OF CARE IN HOSPITALS: THE NEED FOR CHANGE
}

\author{
William Worthington* and LaURens H. Silver $\dagger$
}

\section{INTRODUCTION}

Public concern has recently been focused upon the quality of care provided patients in the nation's public hospitals. Many of the nation's poor are treated in county or city hospitals, yet during the last year both the Boston City Hospital and the St. Louis City Hospital failed to meet the accreditation standards of the Joint Commission on Accreditation of Hospitals (JCAH). ${ }^{1}$ The D.C. Hospital in the District of Columbia was confronted with allegations from its own house staff that it was rendering inadequate and inferior patient care. ${ }^{2}$ In January 1970, a group of seventy

- J.D. 1969, University of Southern California. Staff attorney, National Legal Program on Health Problems of the Poor, School of Law, U.C.L.A., I969-70.

† J.D. 1963, University of Chicago. Trial attorney, Department of Justice, 1963-65. Staff attorney, Neighborhood Legal Services Program of the District of Columbia, 1965-67. Deputy Director of Law Reform, Neighborhood Legal Services Program, 1968-69. Currently Director, National Legal Program on Health Problems of the Poor, School of Law, U.C.L.A.

The authors wish to acknowledge the valuable research assistance of Craig Cullen, J.D. I970, U.C.L.A., and Larry Pett, M.Ph. 1970, U.C.L.A.

${ }^{1}$ For a chronicle of the conditions existing at Boston City Hospital, see Worsley et al., Recommendations and Comments on Boston City Hospital 4 (JCAH survey, June 2-4, I969). The surveyors made the following summary of their findings:

"The attention of the medical staff and administration is directed to the major deficiencies which include failure to properly maintain existing automatic sprinklering systems; lack of automatic fire extinguishing systems ... ; delay in completion of medical records; lack of a sufficient number of graduate registered nurses for full patient coverage; need for additional qualified therapeutic dietitians; need to revise medical staff by-laws; need for relocation of surgeon's dressing room to reduce potential of outside contamination; need for architectural segregation of the labor delivery room and newborn nursery and urgent need for adequate facilities to allow for proper separation of infected gynecological patients from the obstetrical-newborn area. A concerted effort should be made to promptly correct these and other deficiencies in order that accreditation may be attained."

Similar problems exist at the Veterans Administration Center's Wadsworth Hospital in West Los Angeles. See Los Angeles Times, May II, 1970, at 3, Apr. 29, 1970, at 3, and May 26, 1970, at 3. Cook County Hospital in Chicago was recently on the verge of complete shut-down as a result of political interference in the running of the hospital and deplorable patient care conditions. See Chicago Daily News, May 20, 1970. It was given a provisional one-year accreditation by the JCAH on April 26, x970. The St. Louis City Hospital was disaccredited in September 1969, and the Boston City Hospital lost its accreditation January I, 1970. A few months later the latter was accredited provisionally for one year. See 27 MED. CARE Rev. 584-85 (1970). Recently, D.C. General Hospital was also given a one-year provisional accreditation. See HosprTAI WEEK, Sept. 4, 1970, at 36.

${ }^{2}$ For conditions at D.C. General, see generally 26 Med. Care Rev. 996-Io09 (I969). The residents at D.C. General prepared a "Statement of the House Staff Association of the District of Columbia General Hospital Before the Survey Team of the Joint Commission on Accreditation of Hospitals" in May 1970 in anticipation of a JCAH accreditation survey of D.C. General. According to the Statement, the following drugs were unavailable at D.C. General Hospital for at least one wcek during the last year:

"Potassium Chloride (treatment for hypertension); Primaquine (treatment for malaria); Aldomet (treatment for high blood pressure); Quinidine (treatment for heart disease); Ampicillin 
residents in internal medicine at Los Angeles County-University of Southern California Medical Center filed suit in the Superior Court of Los Angeles County in an attempt to enjoin overcrowding at that hospital which resulted in patient beds being placed in corridors. ${ }^{3}$ While these latter two confrontations arose independently, they reflect a nationwide crisis in the system which purports to deliver hospital care to the nation's poor.

The quality of care alleged by these doctors to exist at two of the nation's largest

(treatment for urinary infections); Phenoxymethol Penicillin Potassium Salt (treatment for pneumonia and strep throat); Certain types of insulin ( $U$ 80 and $U$ 40) (treatment for diabetes); Hydralazine (treatment for high blood pressure); Mylanta (antacid); Glyceryl Guaiacolate Elixir (treatment for coughs); Quadrinol (relieves asthmatic wheczing); Stcroid Preparations (four months, treatment for inflammations); Phenylephrine (preparation for dilation); Neosporin (antibiotic); Homatropine (one month, eye drops)."

Statement at 33-34. With regard to medical records, the Statement charged that

"In a recent sampling of 55 requests for patient records made to the medical records department, only one out of six could be retrieved. In another sampling is out of 30 were missing. Because past records often cannot be found, the medical staff is unable to properly cvaluate the patient's previous care, properly plan future care, communicate with other physicians and professionals contributing the patient's care, or provide data for use in research and education."

Id. at 23. As for $\mathrm{x}$-ray facilities, the Statement alleged that

"First, there are considerable delays in scheduling routine $\mathrm{x}$-rays, commonly as long as ro-r 4 days. This is because there are not sufficient competent technical personnel to conduct the services . . . . In addition, $x$-ray pictures are lost with astounding regularity. One physician recently reported the loss of three repeated x-ray studies on one patient within a 24 hour period. . .."

Id. at 36 . Additional comments were made concerning laboratory facilities:

"The laboratory at D.C. General Hospital has recently announced that it will throw away all specimens submitted for analysis after 9:00 a.m. . . because, it is maintained, there are not sufficient personnel to do such analysis before the specimens are too old to work with . . . . Even as to specimens submitted before the deadline, it is sometimes several days before laboratory reports can be obtained, and some house staff physicians maintain they get reports back only $50 \%$ of the time."

Id. at 26 .

${ }^{3}$ Fisher v. County of Los Angeles, No. 6862I (Los Angeles County Super. Ct., filed Jan. 12, 1970).

In a press release accompanying the filing of the litigation, the doctors explained their plight:

"Right now [the] residents are trying to care for 90 new patients a day. The medicine wards constantly run 75-roo beds over capacity. We are turning sick people out in the streets to make room for people who are even more ill. At the same time, this heavy load puts a great strain on the ancillary facilities, the nurses, the labs and others, making proper treatment that much more difficult. ...

"We residents are here to work and learn, but we can do neither with any success under these conditions."

Residents in Internal Medicine, L.A. County Hospital, Press Release, Jan. r2, r970.

The doctors further pointed out that the primary source of overcrowding was from private hospitals in the county, which transfer approximately 1300 patients per month to County-USC Hospital. Many of these are simply unwanted, often critically ill persons who show up in ambulances, unannounced, many times without complete medical records. The suit seeks an injunction against the hospital and county to limit patient load to a number that can be adequately cared for, and to eliminate the practice of putting patients in the hallways and overcrowding wards in violation of state health laws. See CaL. ADMIN. CODE tit. I7, $\$ 257(\mathrm{a}), 348,353,454$. The suit contends, inter alia, that patients are being deprived of life and health without due process of law, that the county is forcing its doctors to practice medicine in a manner which does not comport with medical ethics, and that the county has broken its contract with the doctors to provide a suitable environment for the practice of medicine during their residencies pursuant to the Essentials of Approved Residencies of the AMA Council on Medical Education. With regard to violations of medical ethics, see AMrrican Medical Association, Principles of Medical Ethics (1957). 
hospitals ${ }^{4}$ can only be described as dangerously inadequate and tragically inhuman. Yet their descriptions are consistent with findings of other recent studies of hospital care in America. ${ }^{5}$

Explanations for the inadequacies of these hospitals can be readily advanced. They are publicly owned institutions. ${ }^{6}$ They treat many patients whose personal financial resources are insufficient to pay for the care received. ${ }^{7}$ Although thirdparty insurers and the federal Medicare and Medicaid programs enable some patients to have payments made on their behalf, not all medically indigent patients ${ }^{8}$ are eligible for such coverage. ${ }^{\theta}$ The result is that the government entity which operates the hospital must make up a substantial operating deficit out of general tax revenue. In light of the lack of sufficient revenues for many city governments it is hardly surprising that the public hospitals are forced to operate on a less than adequate budget.

While these factors provide an explanation for the deficiences of the nation's public hospitals, they do not provide a satisfactory justification. The fact that these institutions are caught in a political and economic squeeze ${ }^{10}$ does not entitle them

t Los Angeles County-USC Medical Center ranks first in the nation in outpatient visits (933,576), second in short-term beds (2105), and third in total beds (2105). D.C. General ranks eighteenth, eighth, and twelfth, respectively. American Hospital Association, Annual Survey of Hospitals (rg68 data tape).

'R. Duff \& A. Hollinshead, Sicrness and Society (I968), discusses the attitudes of hospital staff and the quality of care rendered to patients of different social status, as related to the different classes of accommodations within a large teaching hospital. Sparling, Measuring Medical Care Quality: $A$ Comparative Study, Hospitats, Mar. 16 , 1962, at 62, found that the frequency of necessary appendectomy operations-medically justified on the basis of tissue examinations-and the adequacy of the preoperative examination varied with the type of hospital (teaching versus community) and the source of payment. A broad discussion of the inadequacies of U.S. hospitals is well presented in E. HorT, Condition Critical: Our Hospital Crisis (rg66).

${ }^{\circ}$ Of the 7137 AHA-registered hospitals in the United States in 1968,2606 , or $26.7 \%$, were publicly owned and operated. In terms of beds, $33.1 \%$ of U.S. short-term and $95.4 \%$ of U.S. long-term beds were publicly owned. Hospitals (Guide Issue), Aug. I, I969, pt. 2, at 476 .

'Many states impose an obligation upon their county or municipal hospitals to provide medical care for those unable to pay. See, e.g., Cal. Weifare \& Institutions Code $\$$ I7000 (West I966); ANN. IND. STat. $\$ 52-113 I(1964)$.

${ }^{8}$ A medical indigent is a person who cannot afford to provide himself or his dependents with adequate medical care without being deprived of food, clothing, shelter, and other basic essentials of living.

Only Social Security recipients who are 65 years of age or older are eligible for hospital benefits under Medicare. 42 U.S.C. $\$$ I395c (Supp. I, I965). Medicaid, 42 U.S.C. $\$$ I396 et seq. (Supp. I, 1965), eligibility varies from state to state. Only those individuals who meet stringent means tests and other eligibility criteria are eligible. Since it is closely linked to the categorical assistance programs, Medicaid shares all of the glaring faults of our welfare system. In most states, for example, children living at home with both parents, who are needy by virtue of their father's unemployment or underemployment are ineligible for Medicaid benefits. Most states have not exercised their option under 42 U.S.C. $\$ 1396 \mathrm{~d}(\mathrm{a})$ (i) (Supp. I, I965) to provide medical assistance to all needy children. In most states medical assistance is furnished only to children whose families are already receiving categorical assistance payments. 42 U.S.C. § I396a(Io) (Supp. I, r965). Persons who are not categorically "linked" to the federal programs-Aid to the Blind, Old Age Assistance, Aid to the Permanently and Totally Disabled, or Aid to Families with Dependent Children-are not entitled to receive medical benefits under Medicaid. See Stevens \& Stevens, Medicaid: Anatomy of a Dilemma, in this symposium, p. 348 .

${ }^{10}$ The average hospital expense per patient day has increased radically. The increases are primarily 
to endanger the health and destroy the dignity of their indigent patients. While the hospital administrators may be powerless to do anything about the inadequacies of hospital appropriations, there are regulatory bodies charged with ensuring that health care is administered in accordance with minimal professional standards. The underlying question raised by the dissident doctors in Los Angeles and Washington, D.C., is why these regulatory bodies have failed to see that professional and humane medical care is administered in the nation's hospitals.

While that question is now being raised in the context of the public institution, its implications extend to all providers of medical care, whether they be public, voluntary, or proprietary. In this article we will examine this larger question. We will examine the major agencies which regulate the quality of hospital care at the state and national level. We will examine how these agencies are affected by federal health benefits legislation (Medicare and Medicaid) and the role that the federal government is (and is not) playing in maintaining minimum standards of care in the nation's hospitals.

\section{I}

\section{Regulation at the State Level}

Hospital regulation at the state level is a rather recent phenomenon. Prior to World War II, fewer than a dozen states had any laws regulating hospitals. ${ }^{11}$ However, following the passage of the Hill-Burton Hospital Construction $\mathrm{Act}^{12}$ in 1946 , almost every state adopted a hospital licensing act, since such a law was required for participation in the federal program..$^{13}$ The resulting statutes were neither strongly worded nor comprehensively conceived; the states were only required to demonstrate the existence of maintenance and operation standards which

attributable to rising salaries and increased equipment, facilities, and maintenance expenditures. HospITAls (GuIDE Issue), Aug. I, I969, pt. 2, at 469 . An indication of the extent of the increase is given in the chart below:

State and local governmental short-term hospitals Voluntary nonprofit short-term hospitals

\begin{tabular}{cr}
\multicolumn{2}{c}{ expenses/patient day } \\
1960 & 1968 \\
$\$ 29.43$ & $\$ 60.25$ \\
33.23 & 62.18
\end{tabular}
percentage increase 105 86

Similarly, in the decade ending in 1968 , admissions increased by $33 \%$ for state and local governmental hospitals and $24 \%$ for voluntary nonprofit hospitals. Id. at 474-75. In large community teaching hospitals, where many indigent and/or welfare patients are treated, costs have risen to an even greatcr extent. At Massachusetts General Hospital in Boston, for example, average costs per patient day have risen from $\$ 36.50$ in 1959 to $\$ 103.00$ in 1969 -an increase of $x 82 \%$. Mecklin, Hospitals Need Management Even More Than Money, Fortune, Jan. I970, at 96, 99.

11 See H. Fry, The Operation of State Hospital Planning and Licensing Programs 23 (AHa Hospital Monograph Series No. 15, 1965).

${ }_{12} 42$ U.S.C. $\$ 291$ et seq. $(1964)$.

${ }^{13}$ Section 623 (d) of the Hill-Burton Act provided, "If any State, prior to July $x$, 1948 , has not enacted legislation providing that compliance with minimum standards of maintenance and operation shall be required in the case of hospitals which shall have received Federal aid under this title, such State shall not be entitled to any further allotments ..." 42 U.S.C. $\$ 29 \mathrm{rf}$ (d) (I946). 
could be enforced, if necessary. The impact of these state licensing laws on the quality of care rendered in hospitals has been limited.

Although most state regulatory agencies presently have the legal authority to set standards for medical care as well as the physical plant and safety aspects of hospitals, ${ }^{14}$ the latter are more specific and more easily developed and applied than the former. Physical plant attributes are still almost exclusively emphasized at the inspection level. This emphasis is partly the result of the enactment of the state laws contemporaneously with the early stages of implementation of the federal HillBurton program. Both were enacted at a time when legislators felt that it was beyond their competence to attempt to establish standards for the quality of medical care rendered in hospitals. To allay fear that the federal government would gain excessive control over the regulation of health facilities, the powers of the federal government were restricted mainly to establishing construction standards, while operational standard-setting and enforcement were left to the individual states.

The major weakness of the state regulations as they now exist, in addition to their general failure to establish adequate standards relating to the quality of care, is general laxity in enforcement. ${ }^{15}$ Few states have attempted to establish machinery to see that standards are met. ${ }^{16}$ Often the regulations are worded as recommendations rather than requirements; ${ }^{17}$ words like sufficient, adequate, and reasonable are common, especially in standards dealing with patient care. These words cannot

\footnotetext{
16 The purpose of some state hospital licensing statutes is limited to "prescribing minimum standards of safety and sanitation in the physical plant ...." CaI. Health \& SAFETY Code \$ I4IX (West I955). Other hospital licensing statutes confer broad rule-making authority on state agencies, though aspects of physical environment are stressed. See Ill. Star. ANN. ch. III 1/2, $\$$ I47 (1966). Some hospital licensing statutes contain express language oriented to quality of care. In Massachusetts, the hospital must meet "requirements for diagnostic and therapeutic facilities for the study, diagnosis and treatment of patients ...." Mass. ANN. Laws ch. III, $\$ 72$ (Supp. I966). However, even where a state's hospital licensing statute contains language arguably limited to safety and sanitation of facilities, as in California, rule-making authority may be exercised in a broader manner to set standards relating to methods of care, such as proper medical records. Cf. CAL. Admin. Code tit. I7, $\$ 280$.

${ }^{10}$ A survey conducted in 1965 reported that only 37 of the 50 states inspected their hospitals at least once a year; the most common reason for not doing so was "lack of adequate staff." Foster, States Are Stiffening Licensure Standards, Study Shows, MODERN HOSPITAI, Aug. 1965, at 128, 129.

According to a recent survey of state licensing laws conducted for the Public Health Service's National Center for Health Statistics, 47 states had provisions in their law for suspension or rcvocation of hospital licensure. In I 668 there were reported ro formal hearings to show cause why licenses should not be revoked. Twenty-three hospitals had renewal of their licenses refused or had their licenses rcvoked. In 1968 states reporting revocations or refusal to renew were: Alabama (3); Arizona (2); Indiana (2); Michigan (6); Mississippi (I); Nebraska (2); Utah (2); West Virginia (4); and Wyoming (1). Data as to the mean numbers of beds in these hospitals is not reported. Surveys \& Research Corporation, State Laws \& Regulations for Licensing Hospitals, Nursing Homes, \& Other Medical CARE AND RESIDENT CARE FACILITIES table 8A (1969) (report prepared for the National Center for Health Statistics).

${ }^{10}$ In 1965 , Fry pointed out that not one institution of higher education offered any program for the training of directors of licensing agencies. Consequently, directors of licensing bureaus-and their subordinates-derived most of their knowledge and experience from the program itself. H. FRX, supra note $1 \mathrm{I}$, at 88 . Moreover, the persons who do the inspection of health facilities are typically nurses, sanitarians, and engineers.

17 Id. at 43 .
} 
be uniformly understood by most people, nor do they set meaningful guidelines. Low budget appropriations in state regulatory agencies have caused staffing deficiencies and sporadic enforcement, and low pay scales dissuade highly qualified persons from becoming employed as inspectors. ${ }^{18}$ It is often financially necessary to use other offices and state agencies in the enforcement procedure. This creates organizational conflicts which make it even more difficult to attain the objectives of hospital licensure. Finally, education and consultation activities are severely lacking in the programs, in part from a dearth of guidance from voluntary or governmental agencies. The U.S. Public Health Service, for example, has been very reluctant to interfere with state hospital regulations. ${ }^{10}$

With a few exceptions, states have not assumed the responsibility for supervising the quality of medical care rendered in hospitals. Whether by default or design, they have chosen to delegate the responsibility to the medical profession and/or the federal government, neither of which, unfortunately, has adequately provided the needed regulation. Two states, however, New York and Michigan, have recently taken steps to improve their licensing laws and to coordinate planning of health facilities with state licensure programs. These innovative departures will be discussed below. ${ }^{20}$

\section{II}

Certification and Accreditation at the National Level

In addition to licensure by the states, hospitals may be subject to accreditation or certification under national standards promulgated either by a voluntary accrediting body or by the Department of Health, Education, and Welfare. Certification and accreditation are both voluntary evaluations, however, and thus do not have the direct regulatory force of the state licensing standards.

Accreditation of hospitals is a term used to signify that a hospital has met the standards of some recognized group whose sole or primary function is to promulgate and apply standards to hospitals. A variety of accreditational bodies exists for a variety of purposes, ${ }^{21}$ but only one, the Joint Commission on Accreditation of Hospitals, has national recognition and extensive scope. Founded in 1952 out of a precursor organization established by the American College of Surgeons,

\footnotetext{
${ }^{18}$ Id. at 38. See also A. Somers, Hospital Regulation: The Dilemma of Public Policy (1969).

${ }^{10}$ A. Somers, These Are the Questions About Regulation. What Kind? How Much? By Whom? Why?, Modern Hospital, Sept. I969, at 137, I4I.

${ }^{20}$ See, e.g., Mick. Comp. Laws Ans. \$33r.4Ir et seq. (Supp. 1970); N.Y. Pub. Health Law $\$ 2800$ et seq. (McKinney Supp. 1969), discussed in text accompanying notes $56-64$ infra.

21 The major sources of accreditation, in addition to JCAF, are AMA approval for internship and residency programs; cancer program approved by the American College of Surgeons; medical school accreditation by the Liaison Committee of the AMA and Assaciation of American Medical Colleges; professional nursing school approved by the National League for Nursing; practical nurse training program approved by the National League for Nursing; membership in Council of Teaching Hospitals of the Association of American Medical Colleges; and classification as a participating hospital by Blue Cross.
} 
the JCAH is presently a private, nonprofit body composed of representatives from six organized segments of American medicine. ${ }^{22}$ It inspects hospitals on a voluntary basis and grants accreditation upon a finding that the hospital complies with JCAH's self-imposed "standards" of hospital adequacy. ${ }^{23}$ Lack of accreditation, however, places only a limited constraint on the ability of a hospital to operate. ${ }^{24}$ Until recently, JCAH accreditation was primarily a matter of prestige within the medical community and had no effect on a hospital's attractiveness to patients. ${ }^{25}$

Since 1965 , JCAH accreditation has gained more significance, in that accreditation enables a hospital automatically to be certified as a provider under Medicare if it complies with federal utilization review requirements. ${ }^{26}$ However, this linkage of JCAH to federal funding has not necessarily meant any improvement in the quality of hospital care.

In I 665 , at the time of adoption of the federal Medicare and Medicaid programs, JCAH standards were weak in many respects, primarily stressing maintenance of medical records and medical staff organization. ${ }^{27}$ With regard to other areas and functions of the hospital, such as the emergency room and outpatient department, the standards were grossly inadequate. Moreover, JCAH's method of enforcing these standards-usually by sending out a single surveyor once every three years after at least several weeks' notice to the hospital-allowed many hospitals to relax their vigilance, even with respect to these inadequate norms. New standards, however, were drafted by JCAH in October 1969 and approved in April 1970. ${ }^{28}$

${ }^{22}$ The original founding members were the American Medical Association, the American Hospital Association, the American College of Physicians, the American College of Surgeons, and the Canadian Medical Association. The Canadian Medical Association has since dropped out to form its own accrediting body in Canada. Recently, JCAH has added one representative each from the American Association of Homes for the Aging and the American Nursing Home Association.

${ }^{23}$ Any hospital listed with the American Hospital Association and containing a specified minimum of beds can request to be accredited by the JCAH. The hospital is notified several weeks before the visit that an accreditation survey is going to take place. If there is failure to meet the Standards of Accreditation, a hospital may still be granted provisional accreditation. Unfortunately, the Standards do not establish criteria as to when provisional accreditation is appropriate. Current practice is to grant provisional accreditation for one year only, after which the hospital is resurveyed.

"Only a few states have incorporated JCAH standards into their licensing laws and have made JCAH accreditation a condition of licensure; withdrawal of accreditation would have serious implications in such states. Withdrawal of accreditation would also seriously impair a hospital's ability to attract capable residents and interns.

20 While a list is published annually containing names of accredited hospitals, a patient would have no direct way of knowing a hospital had been refused accreditation. The JCAH will not release information concerning which hospitals have had accreditation withdrawn or have been refused accreditation. It will inform the public only whether a hospital is accredited and, if not accredited, whether the hospital applied for accreditation. From this information, it is possible to conjecture which hospitals have failed, but it is first necessary for an astute "consumer" of hospital services to ask the right questions.

2042 U.S.C. $\S$ I395bb (Supp. I, I965).

${ }^{27}$ JCAH, Standards for Hospital Accreditation, in Five Basic Publications of THE JoINT ComaIssion on Hospital Accreditation (I964).

${ }^{38} \mathrm{JCAH}$, Standards for Accreditation of Hospitals (1969). It should be noted that in at least one very significant respect the revision of JCAH Standards may have resulted in lower standards. With regard to the important subject of required consultations, the revised draft only states that "the use of consultations, and the qualifications of the consultant should be revieved as part of medical care 
These standards, to be effective January I, I97I, fail to prescribe standards for outpatient services, fail to consider the adequacy of the hospital staff to meet the patient load, do not articulate a clear responsibility of the hospital to serve effectively a particular patient community, and do not consider patient rights with regard to privacy, choice of accommodation, subjection to experimentation, and participation in clinical teaching programs, for example. Moreover, the JCAH standards fail to examine the quality of care "output" of a hospital. So long as medical staff organization comports with the standards, surveyors are not to be concerned with the substantive findings of tissue review or necropsy committees, no matter how horrendous. Thus even though the quality of care in an institution may be bad, a hospital which has the organizational appearance of peer group review will be accredited. Finally, the Standards and Interpretations do not specify what constitutes substantial compliance with the standards for the purpose of accreditation. These and other issues have been the point of recent criticism by a welfare recipient healthconsumer organization. ${ }^{29}$

The best indication of the ineffectiveness of the JCAH accreditation surveyand the tendency toward perfunctory re-accreditation-is supplied by the fact that in I968, of I30 state and local governmental hospitals registered with the American Hospital Association, I28 were accredited. ${ }^{30}$ Included among the latter were D.C. General Hospital, Boston City Hospital, and such other problem-ridden institutions as Cook County Hospital and Newark City Hospital. All but the last have come under public scrutiny in recent months regarding the deterioration of patient care and staffing. The fact that such institutions are accredited despite obvious and admitted deficiencies attests to the inadequacy of the standards applied by the JCAH and the ineffectiveness of the accreditation program in maintaining hospital quality. Under considerable public pressure, JCAH has recently exercised long overdue responsibility by revoking the accreditations of St. Louis City Hospital and Boston

evaluation." Id. at 22 (Interpretation section to Standard III). The New York licensing provisions discussed in note 56 , infra, contain detailed provisions relating to surgical consultations, particularly in complicated obstetric cases. The former JCAH standards required consultation in such cases and in all cases in which the patient was not a good medical or surgieal risk, the diagnosis was obscure, or there was doubt as to the best therapeutic measures to be utilized. Standards, sispra note 27, at 6 .

${ }^{20}$ A list of 26 demands was presented to JCAH by the National Welfare Rights Organization in Chicago on June 18, 1970. These demands are set forth in Appendix A. See also Modern Hospital, July 1970, at 29-32.

${ }^{30}$ Hospitals (GuTde Issue), Aug. I, 1969, pt. 2, at 494-95. Hospitals may be registered by the AHA when an application form is submitted stating that the hospital ( $r$ ) has at least six beds, and the average length of stay is at least 24 hours; (2) is constructed, equipped, and maintained to insure patient safety and uncrowded and sanitary facilities; (3) will allow physicians to admit patients; (4) has an organized medical staff and bylaws approved by the governing body; (5) shall submit evidence of regular care of the patient by a physician; (6) maintains medical records on all patients; (7) shall makc available nursing services; (8) shall offer services more intensive than those required merely for room and board, personal services, and general nursing care; (9) shall make available minimal surgical or obstetrical facilities, relatively complete diagnostic and treatment facilities, diagnostic $x$-ray services, and clinical laboratory services for all patients. AHA, Requirements for Accepting Hospitals for Registration (approved Feb. 4-5, 1965). For a summary of hospitals approved by JCAFI by number of beds in each state, compared with non-JCAH hospitals in each state by number of beds, see Appendix C. 
City Hospital, and granting one-year provisional accreditations to Cook County Hospital and Detroit General Hospital; ${ }^{31}$ later, one-year probationary accreditations were given to St. Louis City Hospital, Boston City Hospital, and D.C. General Hospital. ${ }^{32}$

Certification of hospitals as providers for the purpose of reimbursement for services rendered to Medicare beneficiaries is performed by the federal government pursuant to the Medicare legislation. Section I86I(e) of the Social Security Act of I965 sets forth certain requirements that must be met by participating hospitals ${ }^{33}$ and empowers the Secretary of Health, Education, and Welfare to establish "such other requirements as the Secretary finds necessary in the interest of the health and safety of individuals who are furnished services in the institution ...."34 Pursuant to this provision, the Secretary has established a detailed set of regulations entitled "Conditions of Participation for Hospitals."

The fundamental weakness of the certification program is its interrelationship with JCAH accreditation. The statutory provision which empowers the Secretary to establish requirements for certification goes on to say that "such other requirements may not be higher than the comparable requirements prescribed for the accreditation of hospitals by the Joint Commission on Accreditation of Hospitals ...." ${ }^{238}$ Thus the statute adopts the inadequate JCAH standards as the ceiling for federal requirements for participation and effectively prohibits the federal government from playing an active role in upgrading hospital quality through the Medicare program.

This subordination of federal standards to JCAH standards is further accom-

\footnotetext{
${ }^{31}$ See Modern Hospital, June I968, at 36, Feb. I969, at 47-48, Feb. 1970, at 36B. See also note I supra.

${ }^{32}$ Hospitals, May I6, I970, at II9; Hospiral WeEk, Sept. 4, I970, at 36. See note I supra.

${ }^{33}$ The act defines a hospital as eligible to participate in the program when it

"( $x$ ) is primarily engaged in providing, by or under the supervision of physicians, to inpatients

(A) diagnostic services and therapeutic services for medical diagnosis, treatment, and care of injured, disabled, or sick persons, or (B) rehabilitation services for the rehabilitation of injured. disabled, or sick persons;

(2) maintains clinical records on all patients;

(3) has bylaws in effect with respect to its staff of physicians;

(4) has a requirement that every patient must be under the care of a physician;

(5) provides 24 -hour nursing service rendered or supervised by a registered professional nurse, and has a licensed practical nurse or registered professional nurse on duty at all times;

(6) has in effect a hospital utilization review plan which meets the requirements of subsection

(k) of this section;

(7) in the case of an institution in any State in which State or applicable local law provides for the licensing of hospitals, (A) is licensed pursuant to such law or (B) is approved, by the agency of such State or locality responsible for licensing hospitals, as meeting the standards established for such licensing ...."

42 U.S.C. $\$ 1395 x(e)(I-7)$ (Supp. I, I965). This and subsequent footnotes refer to the sections as numbered in the codification rather than in the Act.

86 Id. $\$ 1395 \times(\mathrm{e})(8)$.

${ }^{35} 20$ C.F.R. $\$ 405.1001$ et seq. (I970). Similar Conditions of Participation or Coverage have been established for extended care facilities, id. \$405.Iror et seq., home health services, id. \$405.1201 et seq., clinical laboratories, id. $\$ 405$.I30r et seq., and portable $x$-ray services, id. $\$ 405.1401$ et seq.

${ }^{36} 42$ U.S.C. $\$ 1395 \times(\mathrm{e})(8)$ (Supp. I, I965). This provision is subject to an important exception which will be discussed at p. 322 infra.
} 
plished by another provision in the statute. Section 1865 of the act provides in part as follows:

$[A] n$ institution shall be deemed to meet the requirements of the numbered paragraphs of Section $1395 \times(e)$ of this title ... if such institution is accredited as a hospital by the Joint Commission on Accreditation of Hospitals. 37

The federal government has interpreted this section to mean that hospitals which are JCAH accredited may not be inspected or evaluated by state agencies under contract with the federal government to see if they also meet the Medicare Conditions of Participation. ${ }^{38}$ Any hospital which attains JCAH's accreditation can participate in Medicare without ever having been surveyed by those state agencies to determine their compliance with the Conditions of Participation. ${ }^{39}$

Of course, not all hospitals wishing to participate in Medicare are JCAHaccredited. Those without accreditations must be inspected to determine their compliance with the federal Conditions of Participation. However, under current HEW practice, these inspections are conducted by an agency of the hospital's own state, not by employees of HEW. ${ }^{40}$ In almost every state, the agency which conducts the Medicare inspection is the same agency which conducts the state licensing inspections. Thus any weakness in personnel or inspection methods which exist in the state hospital licensing programs are carried over to the federal Medicare pro. gram. Further, the application of the federal Conditions of Participation will vary, according to the varying interpretations and competencies of the state licensing authorities. ${ }^{41}$

Finally, a major difficulty in the application of the Conditions of Participation

\footnotetext{
${ }^{87} \mathrm{Id} . \S \mathrm{I} 395 \mathrm{bb}$.

${ }^{38}$ Interview with Pearl Bierman, Bureau of Health Standards, Health Services and Manpower Administration, Dec. I2, I969. Legislative history sustains this interpretation. The Senate Finance Committce Report accompanying the 1965 Amendments to the Social Security Act states that "Hospitals accredited by the Joint Commission on Accreditation of Hospitals would be conclusively presumed to meet all the conditions for participation, except for the requirement of utilization review." S. REP. No. 404, 89th Cong., Ist Sess. 29 (1965).

${ }^{30}$ The state agency, however, must determine compliance with the utilization review requirements. 42 U.S.C. $\$ 1395 \times(e)(6)$ (Supp. I, 1965).

${ }^{40}$ This practice is based on section 1864 of the act, 42 U.S.C. $\$ 1395$ aa (Supp. I, I965), which says that the Secretary must make contracts with participating states "under which the scrvices of the State health agency or other appropriate State agency (or the appropriate local agencies) will be utilized by him for the purpose of determining whether an institution therein is a hospital ...."

${ }^{4}$ State agency Medicare surveys are reviewed, however, by Bureau of Health Insurance and Public Health Service staff in Social Security Administration regional offices. Additionally, there are program review teams, composed of federal surveyors, who make independent surveys of Medicare facilities to evaluate the state agency's performance and to assure uniform application of the Conditions of Participation. Letter to authors from Morris B. Levy, Assistant Bureau Director, Division of State Operations, Bureau of Health Insurance, Sept. II, I970.

The recently issued report of the Task Force on Medicaid and Related Programs has commented:

"Minimum requirements of training, experience and education for State surveyors for

Medicaid and Medicare and their immediate supervisors should be developed by HEW. The

Department should also be empowered to develop equivalency criteria to be used as a measure in

determining whether individuals meet the minimum requirements for surveyors."

Report of the Task Force on Miedicaid and Related Programs 46 (I970).
} 
to non-JCAH-accredited hospitals lies in the interpretation of the "substantial compliance" provisions of the regulations. One of these provisions, section 405.1002, provides,

For an institution to be eligible for participation in the program, it must meet the statutory requirements of section $186 \mathrm{I}(\mathrm{e})$ and there must be a finding of substantial compliance on the part of the institution with all the other conditions. ... Variations in the type and size of hospitals and the nature and scope of services offered will be reflected in differences in the details of organization, staffing, and facilities. However, the test is whether there is substantial compliance with each of the conditions. ${ }^{42}$

A hospital is considered to be in substantial compliance if

[It] meets the specific statutory requirements of section $186 \mathrm{r}(\mathrm{e})$ but is found to have deficiencies with respect to one or more Conditions of Participation which:

(I) It is making reasonable plans and efforts to correct, and

(2) Notwithstanding the deficiencies, is rendering adequate care and without hazard to the health and safety of individuals being served, taking into account special procedures or precautionary measures which have been or are being instituted. ${ }^{43}$

Hospitals which cannot meet the test of "substantial compliance," as broad and flexible as the Conditions may be, can yet qualify under a special certification category. ${ }^{44}$ This provision was adopted largely out of fear that many eligible recipients living in isolated areas which lacked sufficient facilities would not otherwise have needed hospital services available to them. In addition, hospitals which cannot be certified in any category may be reimbursed by HEW for emergency services rendered to eligible patients. ${ }^{45}$

"Substantial compliance" has been interpreted to mean that the hospital must be in "general" conformity with each of the sixteen Conditions of Participation. ${ }^{46}$ The only standards which must be satisfied for certification are the statutory require-

\footnotetext{
$\$ 20$ C.F.R. $\$ 405.1002$ (1970).

${ }^{83}$ Id. $\S 405.1005(\mathrm{c})$.

"Id. \$405.I0I0 provides that "Where, by reason of factors such as isolated location or absence of sufficient facilities in an area, the denial of eligibility of an institution to participate would seriously limit the access of beneficiaries to participating hospitals, an institution may, upon recommendation by the State agency, be approved by the Secretary as a provider of services."

${ }^{25} I d$. \$405.I0II provides that "An institution which has not been determined by the Secretary as being in compliance with all of the Conditions, or which is not accepted to become a participating hospital may, nevertheless, be paid under the program for emergency services furnished provided it meets requircments of section $\mathrm{I} 86 \mathrm{I}(\mathrm{e})(\mathrm{I})$, (2), (3), (4), (5), and (7) of the Act, as amended." In I968, 35,740 emergency bills were paid (\$9 million total), but the Social Security Administration paid only 4448 emergency bills in 1969 ( $\$ 1.4$ million total). The decrease may be due to provider hospital compliance with title VI and stricter emergency payment criteria. Telephone conversation with Morris B. Levy, Sept. 9, r970.

"Cashman, Bierman \& Myers, The "Why" of Conditions of Participation in the Medicare Program, 83 Pub. Health Rep. 7I4, 7I8 (Ig68).
} 
ments in section $\mathrm{I} 86 \mathrm{r}(\mathrm{e})$; no limit has been set on the number of conditions in which the hospital may be deficient, though in "substantial compliance," so long as the deficiencies are not preventing the hospital from rendering care without hazard to the health and safety of patients and plans are being made to correct the deficiences. The determination of substantial compliance is thus made by individual state agencies. ${ }^{47}$

These mandates are, at best, very basic; at worst, they are ambiguous and open to variation in interpretation. Again, a look at the federal government's statistics can be an indication of its effectiveness in monitoring hospital quality. Recent data indicates that as of June 30 , 1970, there were 1704 hospitals (I90,9I6 beds) certified as providers but with deficiencies. ${ }^{48}$ Another $4 \mathrm{II}$ ( 13,376 beds) were given special "access" certification even though they could not meet the Conditions of Participation because of geographic isolation. ${ }^{49}$ A total of 6799 hospitals are certified. Thus twenty-five per cent are not fully in compliance with the Conditions of Participation. $^{50}$ Recent tabulations by the Social Security Administration indicate there are ninety-eight hospitals (eighty-two general hospitals, six TB, and ten psychiatric) that have applied for participation in Medicare since the program began and are still not participating. None of these hospitals is JCAH-accredited. The mean bed size of the eighty-two general hospitals is fifty-four. The figure does not include hospitals initially denied which later upgraded and were certified. Almost all of the denials were based on applications filed in $1966^{51}$

Since the inception of the program fifty-seven hospitals ( 1627 beds) have been terminated (decertified) for noncompliance with the Conditions of Participation, and are still not participating. Ninety-nine hospitals have voluntarily withdrawn from Medicare, in some instances apparently to avoid involuntary termination. ${ }^{\text {b2 }}$ This data makes it uncertain as to whether or not HEW has followed through with

\footnotetext{
${ }^{47}$ It appears that state Medicare agencies have been furnished some federal guidelines for cvaluating compliance with the Conditions of Participation. "These guidelines explain in detail what the state surveyors should evaluate in determining the nature and severity of each deficiency, and the relative greater significance of certain requirements as opposed to others." Letter of Morris B. Levy, supra note 4r.

${ }^{\$ 8}$ Letter to authors from Morris B. Levy, Aug. 24, r970. Detailed data as to certification status of participating hospitals are set forth in Appendix B.

t2 Hospitals may be certified as Medicare providers under special circumstances despite deficiencics where no other facility is available in a particular geographical area. See 20 C.F.R. $\$ 405.10$ ro (x970).

${ }^{\circ}$ It should be pointed out that the sixteen Conditions of Participation are qualified by a large number of corollary standards. It may be difficult for any one hospital to comply with cach Condition. There are fewer than 600 hospitals participating in Medicare (other than those accredited by JCAH) which have been determined to meet all of the requirements. Letter of Morris B. Levy, stipra note 4I.

Not all deficiencies noted by state agencies necessarily adversely affect the type of care offered patients. For example, there may be instances where a committee may fail to meet each month, or fail to produce timely minutes of its meeting. This would have to be noted as a deficiency, although it might not necessarily reflect on the quality of care offered. The Bureau of Health Insurance further believes it is easier to obtain corrections of deficiencies when a facility is participating in the program and the state agency is able to work with it to obtain upgrading of conditions. Id.

${ }^{51}$ Id.

${ }^{62}$ Id.
} 
its plan "to take a look at our certification experience and to work with state agencies to devise ways and means to upgrade the standards in these hospitals." 53

Certification and accreditation are closely related. Both are voluntary, and neither establishes a sufficient standard of care to make up for the deficiencies in the state licensing laws. Certification is in effect dominated by the JCAH so that the federal government is powerless to set its own standards for Medicare participation. The JCAH is controlled by the medical profession and hospital administrators, and thus far it has failed to take an effective stand with regard to critical aspects of hospital quality. Given this interrelationship of national accrediting and certifying bodies, it seems unlikely that either will take any dramatic steps to raise hospital standards in the immediate future. ${ }^{54}$

\section{III}

\section{Means of Improving Hospital Regulation}

\section{A. State Laws}

Effective steps could be taken for improving hospital regulation in the area of state licensing laws. Two states, New York and Michigan, have already taken steps in this direction, and others would do well to follow their example.

New York has reorganized and extended its hospital regulatory machinery. Under the new Public Health $\mathrm{Law}^{\text {55 }}$ the Health Department was given broad powers to develop a new hospital code. The new code contains comprehensive language covering quality of patient care as well as regulation of construction and financial reporting. In a number of respects the code imposes requirements stricter than JCAH standards or imposes requirements with respect to subjects not covered by $\mathrm{JCAH}$, such as outpatient facility standards. ${ }^{56}$

${ }^{53}$ Cashman \& Meyers, Medicare: Standards of Service in a New Program-Licensure, Certification, Accreditation, 57 Am. J. Pub. Health II07, III5 (1967). It may be further noted that after Boston City Hospital lost its accreditation in early 1970, the Medicare Conditions of Participation were applied to the hospital. It was found to be in substantial compliance therewith and has never stopped receiving Medicare payments.

Et It should be noted, however, that the $1970 \mathrm{JCAH}$ standards represent a substantial improvement over the grossly inadequate 1964 version. In addition, $\mathrm{JCAH}$ has recently taken steps to improve its survey procedures by experimenting with three-man survey teams. Henceforth, surveys will be conducted evcry two years rather than every three years.

¿E N.Y. Pub. Health Law $\$ 2800$ et seq. (McKinney Supp. I969).

EB The New York Hospital Code, Io N.Y.C.R.R. $\$$ 700.I et seq. (1969), contains a number of other provisions relating to quality of care which should be noted. With regard to ambulatory services, section 703.3 provides that facilities must submit to the department a plan providing for "comprehensive medical evaluation for such patients on a periodic basis" and for "continuity of care when such patients require hospitalization, home care or emergency care when such services in the facility are not available." Further, that section provides that outpatient facilities should schedule "not more than five patients per hour with an allowance of at least 30 minutes for the first complete patient workup."

Hospitals are also required to establish written admission and discharge policies, including rules governing emergency admissions and policies concerning advance deposits, insurance agreements, and other financial considerations. Id. $\$ 720.7(\mathrm{a})$. No patient is to be transferred when such transfer would create a medical hazard to the person unless such transfer is considered by a physician to be 
Also, the inspections in New York are now carried out by five-man interdisciplinary teams made up of full-time, board-certified physicians, hospital administrators, and allied health professionals. The inspectors are well paid and well qualified. Finally, prior to construction of all hospitals, the approval of the state commissioner must be obtained to insure that the public need exists and to prevent duplication of facilities. ${ }^{57}$

Michigan has also adopted a comprehensive hospital licensing law. ${ }^{68}$ Under this statute, broad power is conferred on the state director of public health to set standards for quality of care in all hospitals. ${ }^{50}$ The statute further provides for the establishment of a state health council to advise and consult with the director of public health in carrying out his responsibilities under the hospital licensure law. ${ }^{00}$ This twelve-member council is appointed for four-year staggered terms by the governor with the approval of the state senate. A prestigious, high-level policysetting body is thus provided to which representatives of consumer interests may be appointed. The state statute further provides that "standards ... for the operation and maintenance of hospitals shall be not less than is required for the certification of hospitals under Public Law 89-97,"61 thus incorporating by reference the federal standards for certification for Medicare discussed above. The Michigan statute in effect requires all Michigan hospitals to comply with JCAH standards. The statute also provides for flexibility in enforcement of the standards. The state director has the power to revoke or deny hospital licenses and to suspend issued licenses at any time. $^{62}$ Furthermore, licenses, when issued, are generally valid for only one year,

in the person's best interest despite the potential hazard of movement. A transfer may be made "only after prior notification to an appropriate medical facility." Id. $\$ 720.7(\mathrm{j})$. Another provision of interest in protecting indigent patients is the requirement that no patient receiving services under Medicaid "shall be deprived the right of free choice of a duly qualified physician on the medical staff of the hospital regardless of the type of bed accommodation to which the patient may be assigned." Id. $\$ 720.7(\mathrm{~m})$. With regard to emergency rooms, the Code requires, inter alia, that hospitals "having 40,000 or more emergency room visits annually shall have a full-time attending or resident physicianin-charge and he or a physician-designee shall be accessible 24 hours a day." Id. $\$ 720.17$ (a). A committee of the medical staff must review clinical and research work performed in the hospital "for the purpose of ascertaining whether clinical investigations of patients are being performed with the written and informed consent of the patients." Id. \$72r.r(c)(2). Detailed rules are set forth with regard to the necessity of surgical consultations, particularly in complicated obstetric cases. Id. $\$ 721.1$ (c)(3). Surgery and treatment of complicated obstetric cases are restricted to board-certified physicians. These regulations were promulgated pursuant to authority conferred by the state's public health law. N.Y. PUB. HEALTH LAW $\$ 2803$ (McKinney Supp. I969).

${ }^{67}$ N.Y. PUB. HeAITH LAW $\$ 2802$ (MCKinney Supp. 1969).

${ }^{68}$ Mich. Comp. Laws ANn. $\$ 33$ I.4II et seq. (Supp. 1970).

To The statute provides that

"[the state director] shall establish a comprehensive system of licensing for all hospitals in the state in order to protect the public through the assurance that hospitals provide the facilities and the ancillary supporting services necessary to enable a high quality of patient care by licensed physicians. All hospitals ... shall meet the minimum standards authorized by this act ...."

Id. $\$ 33 \mathrm{~T} .4 \mathrm{Ir}$.

${ }^{60}$ Id. $\$ 331.413$. The health council is also given the power to advise and consult with the state director of public health concerning the administration of the state's Hill-Burton program.

${ }^{81}$ Id. $\$ 331.415$.

62 Id. $\$ 331.423$. 
thus insuring frequent inspection for compliance. Finally, the statute takes steps to clarify the lines of authority between a hospital's governing board and its medical staff by placing responsibility for the operation of the hospital on the governing body and requiring that body to ensure an adequate system of medical review among the medical staff. ${ }^{63}$ Medical review plans may be submitted for the approval of the state director, although this is apparently not mandatory.

\section{B. Changing the Role of JCAH}

In addition to strengthening the state licensing laws and their enforcement ${ }^{64}$ it is necessary to re-evaluate the role of the federal government in establishing quality of care standards. In particular, a careful examination must be made of the relationship between JCAH accreditation and Medicare certification.

JCAH considers itself a private accrediting body responsive to the needs of its subscribers. More significantly, it represents a particular interest group in the medical care field. It is true that both doctors and hospital administrators are represented on the Governing Body, and that these two groups have quite divergent views on many quality of care issues. However, this diversity does not make up for the fact that the consuming public is not represented in JCAF. The internecine disputes of doctors and hospital administrators may be negatively correlated to the most critical public interests in hospital quality ${ }^{65}$ It cannot be said that the voting

\footnotetext{
${ }^{O B} I d . \$ 331.422$.

of With respect to Medicaid, section Igoza(22)(B) of title I9, 42 U.S.C. $\$ 1396 a(22)$ (B) (Supp. I, 1965), requires states to describe in their state plans "the standards, for private or public institutions in which recipients of medical assistance under the plan may receive care or services, that will be utilized by the State authority or authorities responsible for establishing and maintaining such standards." No minimum federal standards or Conditions of Participation are established in Medicaid. Therefore states are completely free to prescribe their own standards. A preliminary survey of state plan material has indicated that most states have simply prescribed that hospitals be licensed under state law; a substantial number of states have further required that the hospital be a certified Medicare provider. It appears that no state has adopted a separate set of standards for regulating hospital quality of care for title XIX purposes. The recently issued report of the Task Force on Medicaid and Related Programs has highlighted the need for uniform Medicare and Medicaid standards.

"A legislative amendment is needed requiring uniform provisions and unified State standardsetting, certification, and consultation functions with respect to providers of service under both Medicaid and Medicare. (To the extent possible, also, consistent with desired State flexibility to exceed Federal minimum standards, State-controlled licensure of health facilities and agencies should be integrated with those related functions.) The State agency with primary responsibility for health functions in the State should be responsible for all standards functions. Incentives, guidance and assistance should be provided to the States in bringing this about."

Report of the Task Force on Medicaid and Related Programs 46 (I970). H.R. I7550, 9ist Cong., 2d Sess. (1970), the proposed Social Security Amendments of 1970, would have strengthened the state agency standard-setting functions, for, as passed by the House of Representatives, section 238 (a) provided that the state health agency would be responsible for establishing review of the appropriateness and quality of care and services furnished to recipients of medical assistance under the plan. H.R. 17550 did not pass finally in the 9 Ist Congress but is scheduled to be reintroduced in some form in the $92 \mathrm{~d}$ Congress.

${ }^{\circ}$ These internecine disputes primarily involve responsibility for medical care in the hospital and basically raise the question: Who runs the hospital? Hospital administrators and doctors have substantially varying opinions on this critical subject.
} 
members of JCAH represent an adequate cross section of informed opinion on the quality of care so as to properly protect the public interest in this area. ${ }^{\mathbf{0 B}}$

This lack of public accountability on the part of JCAH would not be so critical were it not for the fact that JCAH standards have been imposed as ceilings for the purpose of Medicare participation by provider hospitals. Yet the nature of its voting membership may prevent it from setting standards at a level which is beneficial to the consuming public. ${ }^{67}$ There is a great danger that JCAH will tend to favor the interests of physicians and hospitals at the expense of the public.

Though JCAH does not have power to exclude a hospital from Medicare participation, it does have the effective power to include hospitals that the federal government might otherwise choose to exclude. This power is very critical when quality of care is at issue. ${ }^{68}$ Even more critical is the fact that JCAH has control

\footnotetext{
${ }^{60}$ Recently a coalition of consumer groups, including the National Welfare Rights Organization, American Paticnts Association, and Consumer Federation of America, have sought representation on the board of JCAH, and the JCAH agreed to consider the issue of consumer representation. At time of writing, no decision has been reached.

${ }^{87}$ For example, doctors and administrators are particularly sensitive to such questions as malpractice liability. As such, they are likely to take particular care to prevent JCAH from establishing minimum standards at a level that would tend to raise the legal standard of "due care" in a malpractice suit. Their special interest and defensive attitude in this area could prevent JCAH's adoption of a standard which would be very desirable from the patient's point of view.

${ }^{68}$ This power, together with the fact that $\mathrm{JCAH}$ represents a particular constellation of groups with interests not identical to those of patients, raises some questions concerning whether Congress acted constitutionally when it incorporated JCAH standards into Medicare by creating a conclusive presumption that JCAH-approved hospitals complied with the Conditions of Participation and prohibited the Secretary from developing Conditions that would be higher than comparablc JCAH standards. It is critical to note that Congress did not adopt by reference existing JCAH standards but in effect delegated the authority to JCAH to promulgate standards in the future with regard to accreditation of hospitals. These future standards are to be a binding ceiling on the standards set by the Secretary, and if JCAH were to lower its requirements the Secretary would have to change the Conditions of Participation. Many such delegations to a private entity of prospective rule-making authority have been invalidated in the state courts. See, e.g., Group Health Ins. v. Howell, 40 N.J. 436, I93 A.2d ro3 (1963); Fink v. Cole, 302 N.Y. $2 \times 6,97$ N.E.2d 873 (I951); State v. Emery, 55 Ohio St. 364,45 N.E. 319 (1896); Hillman v. Northern Wasco County People's Util. Dist., 213 Ore. 264, 323 P.2d 664 (1958); State ex rel. Kirschner v. Urquhart, 50 Wash. 2d r3I, 310 P.2d 26r (I957).

While the delegation-of-authority doctrine has been historically suspect since Schechter Poultry Corp. v. United States, 295 U.S. 495 (1935), and Carter v. Carter Coal Co., 298 U.S. 238 (1936), it should be noted that the Carter case, which involved delegation of authority to a group of produccrs and workers in the coal industry to reach industry-wide binding agreements with regard to wages and prices, has never been expressly overruled. Commentators, of course, have been critical of Carter. See, e.g., Jaffe, Law Making by Private Groups, 5I HaRv. L. Rev. 20r (1937). Substantial critiques have been made of the state delegation cases also. See Note, The State Courts and Delegation of Public Authority to Private Groups, 67 HaRv. L. Rev. I398 (I954).

Federal courts which have considered delegations to private groups have sustained such delegations where the standards of the private association are subject to the approval of a federal agency. See R.F. Johnson \& Co. v. SEC, 198 F.2d 690 (2d Cir. r952); McManus v. CAB, 286 F.2d 4I4 (2d Cir. I96I). See also Crain v. First Nat'l Bank, 324 F.2d 532 (9th Cir. I963), in which the court sustained a delegation by distinguishing between a delegation to a private entity of ministerial functions and a delegation of rule-making functions. The power delegated to the JCAH is tantamount to prospective rule-making power; moreover, the Secretary of HEW does not "approve" JCAH standards revisions. While the delegation argument has disturbing implications in that it might invalidate statutes that make entry into the professions conditional upon graduation from accredited schools (in cffect a legislative delegation of prospective rule making), perhaps it is best to quote Professor Davis on dele-
} 
over what type of quality standards will be applied. ${ }^{69}$ So long as the doctors and hospital administrators believe that low standards are beneficial from their point of view, the federal government is powerless to require higher standards as a condition to reimbursement under Medicare. The result is that a hospital can be certified for participation in Medicare even though the Bureau of Health Insurance may suspect or know that the hospital is not a safe place for the treatment of elderly patients. $^{70}$

The most effective step that could be taken to improve the Medicare certification scheme would be to make the Medicare program independent of JCAH. This very step has been strongly recommended by the Health Insurance Benefits Advisory Council (HIBAC) in its 1967 report to Congress. ${ }^{71}$ Its report contained the following language:

The Council believes ..., that it is inappropriate to continue statutory delegation to a private agency of all the Government's authority to safeguard quality of care paid for by a government program. The authority to establish policy on minimum quality should be retained by the Government. Quality standards under Medicare should not be controlled by a private agency's standards. Furthermore, the power of oversight and assurance that standards are applied adequately in individual situations should and must remain within both the responsibility and authority of the Government. In the case of Medicare, the Council has found reason for concern that JCAH standards are not applied with the frequency of inspection and range of inspector skills necessary to assure a high degree of effectiveness. Furthermore, because of present statutory provisions ... the JCAH standards in some cases impose an undesirably low ceiling on the maximum level at which health and safety standards under Medicare may be set. ${ }^{72}$

However, Congress has taken no steps in that direction.

Some of the difficulty with the present Medicare legislation could be avoided by an alternative interpretation of the statute. The power of JCAH is established in the statute by the following language:

The term "hospital" [as used in this statute] means an institution which ... (8) meets such other requirements as the Secretary finds necessary in the interest of health and safety of individuals who are furnished services in the institution, except that such other requirements may not be higher than the comparable requirements prescribed for the accreditation of hospitals by the Joint

gation of authority: "The case law has not crystallized any consistent principles, either in the federal courts or in the state courts." I K. Davis, Administrative Law Treatise \$2.14 (1958).

${ }^{\circ 0} \mathrm{HEW}$ has taken the position that it can adopt no standards which are more strict or more comprehensive than JCAH standards, even with regard to subject matter on which JCAH has not spoken. See note 74 infra.

${ }^{70}$ The report of the JCAF inspection team is held in the strictest confidence by JCAF and is not even released to HEW. Apparently HEW has protested this policy but has never challenged its legal validity in court.

${ }^{71}$ HIBAC was established by the Medicare legislation to monitor the program and make annual reports to Congress concerning the need for changes in the legislation. See 42 U.S.C. § 1395 dd (Supp. I, $1965)$.

${ }_{72}$ Hibac, 1966-67 Annual Report on Medicare 9. 
Commission on Accreditation of Hospitals (subject to the second sentence of section I395z of this title). ${ }^{73}$

The federal government has interpreted this section very narrowly. The Department of Health, Education, and Welfare has drafted the federal Conditions of Participation to follow very closely the Ig65 JCAH standards. They cover no areas not covered by the JCAH standards. Apparently, HEW has taken the position that the statute prohibits it from establishing any more comprehensive standards. ${ }^{74}$ Thus, in effect, HEW has read the statutory language to mean that the JCAFI standards shall be adopted by the federal government practically word for word.

The statute does not require this interpretation. It only prohibits the adoption of federal standards which are higher than comparable JCAF standards. It contains no prohibition against the federal government promulgating standards in areas not covered by the JCAH standards (such as outpatient clinic standards, standards relating to patient privacy, and so forth). Given the narrow scope of the JCAH standards, it would seem that the statute would permit federal regulation in areas not covered by the JCAH standards. Such regulation could have a significant effect on quality of care within a number of critical areas.

We have already noted, however, that hospitals which are JCAH-accredited need not satisfy the Secretary's Conditions of Participation and must only comply with the utilization review standards. ${ }^{75}$ Thus, even though one might argue that the statute does not bar the Secretary from developing Conditions of Participation with regard to those matters not addressed in the JCAH standards (for example, outpatient care), such standards would be applicable only to the distinct minority of smaller hospitals that are not JCAH-accredited. It is clear, then, that the Secretary is effectively dependent upon the standards promulgated by the JCAH. To the extent he has any authority to promulgate higher standards in noncomparable areas they would be applicable only to a very limited number of hospitals.

Another critical section of the statute is the second sentence of section 1863 which provides,

Such conditions prescribed [by the Secretary under section $\mathrm{x} 395 \mathrm{x}$ ] may be varied for different areas or different classes of institutions or agencies and may, at the request of a State, provide higher requirements for such State than for other States; except that, in the case of any State or political subdivision of a State which imposes higher requirements on institutions as a condition to the purchase of services (or of certain specified services) in such institutions under

${ }^{73} 42$ U.S.C. $\$ 1395 x(e)(8)$ (Supp. I, r965). The effect of the second sentence of section $1395 z$ will be discussed at pp. 322-23 infra.

74 This was confirmed in an interview by one of the authors with Pearl Bierman, supra note 38. Miss Bierman indicated that it was HEW's position that if JCAH chose to lower or omit certain standards, HEW was bound to do the same. HEW's position contains the latent premise that JCAF's failure to address a particular aspect of quality of care is tantamount to an assertion by JCAH that such an aspect is not to be subject to standards. The legislative history of title XVIII lends support to neither position and does not illuminate the meaning of the word "comparable" in 42 U.S.C. $\$ 1395 \times(c)(8)$.

${ }^{76} 42$ U.S.C. $\$ 1395 x$ (e)(6) (Supp. I, 1965). 
a State plan approved under subchapter I, XVI, or XIX of this chapter, the Secretary shall impose like requirements as a condition to the payment for services (or for the services specified by the State or subdivision) in such institution in such State or subdivision. ${ }^{76}$

This provision allows the states to apply higher standards to hospitals for the purpose of Medicare certification if they so choose. The statute provides two mechanisms to accomplish this. First, the states may request the Secretary to apply higher standards in certifying Medicare hospitals; alternatively, if the states have higher standards for their title XIX (Medicaid) program, the title XIX standards will be applied for the purpose of Medicare certification. At the present time, no state has either sought permission from the Secretary to apply higher standards, nor has any state prescribed higher standards for its title XIX program. ${ }^{77}$ Moreover, the statute clearly excepts the situation where there are higher state standards from the general rule that JCAH accreditation is sufficient for the purpose of certification:

Except as provided in the second sentence of section $1395 \mathrm{z}$ of this title, an institution shall be deemed to meet the requirements of the numbered paragraphs of section $1395 \times(e)$ of this title (except paragraph (6) thereof) if such institution is accredited as a hospital by the Joint Commission on Accreditation of Hospitals. ${ }^{78}$

Where there are higher state standards, the hospital must comply with those standards regardless of accreditation status. Thus, while it may be true that HEW may not ordinarily contract with a state agency to inspect a JCAH-accredited hospital, it is required to arrange for the inspection of all hospitals in a state which has either requested the Secretary to apply higher standards for Medicare certification or which has established higher standards for participation in a title XIX program. In a state with a title XIX program, the federal government is required to apply any higher title XIX standards to all hospitals which seek to participate in title XVIII even though those hospitals may be JCAH-accredited. This is an important power which the states have not chosen to utilize.

Title XVIII must be amended to provide the Secretary with greater power to promulgate appropriate standards for hospitals participating in Medicare, thereby removing the JCAH ceiling on Conditions of Participation. The Health Insurance Benefits Advisory Council's Recommendation 3 provides that

The Council recommends legislation which would remove the present limitations on the Secretary's authority to establish health and safety standards for hospitals, contained in Section 1865 of the Social Security Act, so that:

The Secretary would have the authority to establish health and safety standards for hospitals commensurate with his authority to establish such standards for other providers of services and for independent laboratories.

\footnotetext{
${ }^{70} \mathrm{Id}$. $\$ \mathrm{r} 395 \mathrm{z}$.

${ }^{77}$ Letter of Morris B. Levy, supra note 41.

${ }^{78} 42$ U.S.C. $\S$ I 395 bb (Supp. I, I965).
} 
The Secretary may, in the case of any national accrediting body with standards and certification procedures equal to or higher than those established by the Secretary for a class of providers or independent laboratories, find that such accreditation provides reasonable assurance that the conditions of participation are met. ${ }^{70}$

It would further appear necessary, in light of the recommendations of the Health Insurance Benefits Advisory Council, first to amend section 1865 of the statute, which provides that JCAH accreditation shall constitute compliance with the Conditions of Participation. At a minimum, the statute should be amended to provide that JCAH accreditation shall constitute only prima facie evidence of compliance with the Conditions of Participation. The Secretary should have the authority to instruct the state agency performing the certification inspection function to apply the Conditions of Participation even though a hospital is accredited. This power -is particularly necessary in view of the fact that JCAH accreditation has been until recently for a three-year period. Even though a hospital might be applying for certification as a Medicare provider over two years from its last accreditation, under present law the Secretary has no power to apply the Conditions of Participation or seek any inspection of the hospital by the state agency. Likewise, even though section 1007 of the Secretary's regulations gives the Secretary power to find that an institution is no longer in compliance with the Conditions of Participation if

The institution has deficiencies of such character as to seriously limit the capacity of the institution to render adequate care or which place health and safety of individuals in jeopardy, and consultation to the institution has demonstrated that there is no early prospect of such significant improvement as to establish substantial compliance as of a later beginning date . . ..$^{80}$

This section applies only to unaccredited hospitals. A hospital which has had ample opportunity to prepare for the JCAH accreditation team visit and is consequently accredited may, soon after the accreditation visit, be in a state of noncompliance with JCAH standards and the Secretary's Conditions of Participation. Under the Secretary's current powers, he would have no power to reinvestigate the hospital after it had been certified as a Medicare provider-even if as much as two years had elapsed since the initial accreditation. Such a situation was illustrated the time of the events which took place at D.C. General Hospital in the District of Columbia, for the conditions complained of at that institution had become manifest near the end of the three-year accreditation period. Any amendment in title XVIII must make it clear that the powers which the Secretary has under section roo7 of the regulations to find a hospital in noncompliance with the Conditions of Participation applies regardless of the accreditation status of the hospital.

As indicated earlier, there are a number of reasons for eliminating the virtually

\footnotetext{
${ }^{79} \mathrm{HIBAC}$, supra note 72 , at Io.

${ }^{80} 20$ C.F.R. $\$ 405.1007$ (a)(2) (1970).
} 
exclusive power of the Joint Commission on Accreditation of Hospitals to promulgate standards for the participation of hospitals in title XVIII by repealing that part of section I86Ie which makes JCAH standards the ceiling for hospital providers under Medicare. First of all, the Joint Commission is entirely dominated by producer groups. Nineteen of the twenty members of its executive body, including representatives of the American Hospital Association, are doctors. The Joint Commission has primarily consulted producer groups in the articulation of its standards. Further, the Joint Commission's policy with regard to inspection reports has been to treat them as a confidential document to be released only to the hospital which has contracted for the accreditation. Inspection reports have not been made available even to the Department of Health, Education, and Welfare. ${ }^{81}$ Nor does the Joint Commission have currently a suitable mechanism for the processing of patient or house staff grievances concerning quality of care. ${ }^{82}$ In sum, though functioning in a quasi-public status by virtue of the substantial standard-setting functions delegated to it by Congress under title XVIII, the Joint Commission has operated as a totally private body unaccountable to the public or to the government..$^{83}$

\footnotetext{
${ }^{81}$ Contents of the JCAF inspection reports become public only when they are released by the contracting hospital.

${ }^{82}$ The JCAH may be in the process of officially codifying such a grievance hearing procedure with regard to accreditation inspections. Two of the consumer demands made to JCAH were that:

“. . A formal procedure should be established for the submission of complaints to the Commission. The procedure should include provision for surprise inspections to be made by the Commission upon a showing of good cause. Also, there should be a mechanism for appeal if the complaint is not acted upon.

"Surveyers must hold confidential interviews with selected members of the various echelons of the medical staff, as well as with any representative of any organized segment of the medical staff, allied professional health workers, or other hospital employees, whenever such meetings are requested during the course of an accreditation inspection, in order to determine their evaluation of the quality of care rendered by the hospital services with which they are most familiar. Surveyors should also, on a random basis, interview selected patients in each major service, including the emergency service. Where requested by the community served by the hospital, a hearing should be held, wherein the community can voice views and comments concerning the hospital. Notice of a pending accreditation must be posted in clear and conspicuous places throughout the hospital so that all medical staff, including house staff and other hospital employees have an opportunity to request a meeting with the surveying staff."
}

In fact, at the request of house staff and community groups in the District of Columbia such a public hearing was held shortly after the completion of the accreditation visit. The accreditation team heard complaints from house staff, ex-patients, and community representatives concerning conditions at the hospital. A lengthy document containing evidence of violations of JCAH standards was presented to the surveyors. It is not known to what extent JCAH has considered the allegations of staff and community. Since these inspection reports are considered confidential documents, is is doubtful that staff and community representatives will ever know whether findings were made with regard to their complaints.

${ }^{83}$ As to the quasi-public status of accrediting bodies like JCAH, see Note, 67 HARV. I. REV. I398, supra note 67; Comment, The Legal Status of the Educational Accrediting Agency: Problems in Judicial Supervision and Governmental Regulation, 52 CoRNeLL L.Q. I04, II7 (I966). The term quasi-public denotes legal obligations to perform the accrediting function fairly and objectively with procedural devices for appeal of a decision not to accredit. The extent of these procedural obligations, and the devices for achieving such objectives, have not been delineated by the courts. The U.S. Court of Appeals for the District of Columbia has recently considered the obligations of a voluntary educational accrediting body to accredit a proprietary institution and has held that because of the nature of proprietary institutions, the voluntary accrediting association need not extend its evaluation to such an institution. Marjorie Web- 
Thus, while the Secretary should be guided to some extent by JCAH standards, as revised in October 1969 , he should be left free to develop his own standards with regard both to areas pertaining to quality of care comparable with JCAH standards and to noncomparable quality of care criteria. To the extent that the Secretary arguably already has the power to promulgate noncomparable standards, as argued earlier, amendment would not be necessary, but clarification still desirable.

\section{Other Recommendations for Reform}

Other areas of reform include building into the certification process adequate mechanisms for the processing and consideration of consumer and staff complaints concerning the quality of care being offered by the hospital. During the course of the crisis at D.C. General Hospital during the winter of 1969-70, house staff of the hospital requested a hearing both before the state agency and the Secretary of Health, Education, and Welfare wherein they could present evidence under section Ioo of the regulations to prove that the hospital had deficiencies "of such a character as to seriously limit the capacity of the institution to render adequate care or which place health and safety of individuals in jeopardy."

Such requests for a section roo "hearing" were denied both by the state agency and by HEW on the ground that the hospital was already accredited and therefore section 1007 did not apply. Neither agency in its reply addressed the question of providing a forum to dissident medical staff or the community for the presentation of evidence concerning quality of care at the hospital. No "hearing" appears to be provided for either under the agreement by the Secretary with the state agency to perform title XVIII certification monitoring or in the Secretary's regulations, or in the statute itself. ${ }^{84}$ It would appear appropriate to make explicit statutory provision for the submission by consumers and hospital staff of evidence to the Secretary for the purpose of either supplementing the recommendations of the state agency with regard to certification or providing evidence upon which the Secretary could exercise his powers to decertify under section 1007 of the regulations. Of further critical importance would be a statutory mechanism whereby adequately documented consumer and/or staff complaints could trigger a section roo proceeding by the Secretary. ${ }^{85}$

ster Junior College v. Middle States Ass'n of Colleges \& Secondary Schools, 432 F.2d 650 (D.C. Cir. June 30,1970 ).

${ }^{86}$ See 20 C.F.R. $\$ 405.1502$ (a) (1970), which requires the Secretary to make findings of fact and conclusions as to compliance of a participating institution with the Conditions of Participation.

${ }^{85}$ There would appear to be no due process right for patients and dissident medical staff to participate in the Secretary's certification function by submitting evidence, even through informal hearings, on the issue of noncompliance with his Conditions of Participation. Such participation, however, would be desirable for the reasons outlined above. Recently, the U.S. Court of Appeals for the District of Columbia ruled that welfare recipients have standing to intervene in conformity hearings called by HEW against particular states on matters pertaining to the administration of federal welfare programs. National Welfare Rights Organization v. Finch, 429 F.2d 725 (D.C. Cir. 1970). In this case, however, a formal hearing was afforded by statute, and the sole question before the court was whether welfare recipients could intervene therein on the issue of nonconformity. Under Medicare no hearing is afforded 
Further, the Secretary should be required, in performing his certification function, to make explicit findings on the evidence presented to him. Of course, an amendment of the statute would be required so as to provide for the applicability of section roo7 despite JCAH accreditation and to provide further that JCAH accreditation shall be only prima facie evidence of compliance with the Conditions of Participation.

\section{ConcLusion}

Since there would appear to be growing interest by consumer groups in the quality of care in municipal and voluntary hospital settings, and an increasing interest on the part of house staff, particularly at large urban and county public hospitals, in quality of care issues, it would seem to be of critical importance to provide institutional mechanisms to address the questions raised as to quality of care. Since many of these issues affect the elderly, Medicare would appear to be an appropriate program for the hearing of and resolution of complaints concerning quality of care in hospitals. In order, however, for there to be effective redress mechanisms and adequate quality-of-care standards, the power of the Department of Health, Education, and Welfare with regard to certification of hospitals as providers under Medicare must be augmented. This would require amendment of the Social Security Act in the manner recommended by the Health Insurance Benefits Advisory Council. In view of the extensive powers granted by Congress to the producerdoctor dominated Joint Commission on Accreditation of Hospitals under title XVIII, it would appear that the HIBAC recommendations should be implemented.

to providers or other interested parties under the statute with regard to the certification of hospitals. In a similar situation, involving the right to judicial review by a competitor bank of the authorization granted by the Comptroller of Currency to establish a branch of a national bank, it was held that neither due process nor the Administrative Procedure Act required the holding of an administrative hearing for that decision. First Nat'l Bank v. Saxon, 352 F.2d 267 (4th Cir. 1965), aff'd, 385 U.S. 252 (I966). Dissenting, Judge Sobeloff argued,

"Rightly, I think, the majority holds that this interest is sufficient to entitle the Smithfield bank to appeal from the Comptroller's decision granting the application. Smithfield contends, however, that this right of appeal is meaningless unless it has previously been given an effective chance to be heard before the Comptroller reaches his final decision on the merits of the application. With this contention I agree, and would hold that such an opportunity, if requested, is a prerequisite to a valid decision on the part of the Comptroller. The right of the plaintiff to appear is of little worth to it if there is no disclosure of the pertinent data and if the Comptroller may make up his mind in a private huggermugger with the applicant.

....

"Smithfield's argument is that it should be allowed to inform itself and express its views before the Comptroller arrives at his decision which will be accorded a large measure of finality in any appeal."

352 F.2d at 273-74. See also Hahn v. Gottlieb, 430 F.2d r243 (rst Cir. Aug. I4, I970), in which it was held that tenants had no constitutional right to a hearing before FHA approval of rent increases in $\$ 22 \mathrm{I}(\mathrm{d})$ (3) housing. 


\section{APPENDIX A \\ Demands of the National Welfare Rights Organization \\ Presented to the Joint Commission on Accreditation of Hospitals \\ June 18 , I970, as revised (June 26, I970, draft)}

I. Where audit of a hospital's emergency room or its records pertaining to initial advice or appraisal required under the Emergency Services Principle indicate that applicants for services in the hospital are applying for non-emergency services due to lack of alternative facilities in the area, the hospital must establish outpatient clinics or satellite ambulatory clinics located in the community served by the hospital. The Commission must establish principles for outpatient care and ambulatory clinic evaluation.

2. A formal procedure must be established for the submission of complaints to the Commission for findings of fact to be made as to such complaints, and for specific action on such complaints if the facts are found to be true. The procedure should include provision for surprise inspections to be made by the Commission in order to determine the factual basis for such complaints. Also, there must be a mechanism for appeal to the Commission if the complaint is not acted upon or the complainant is dissatisfied with Commission action on his grievance.

3. Surveyors must hold confidential interviews with selected members of the various echelons of the medical staff, as well as with any representative of any organized segment of the medical staff, allied professional health workers, or other hospital employees, whenever such meetings are requested during the course of an accreditation inspection, in order to determine their evaluation of the quality of care rendered by the hospital services with which they are most familiar. Surveyors should also, on a random basis, interview selected patients in each major service, including the emergency service. Where requested by the community served by the hospital, a hearing should be held, wherein the community can voice views and comments concerning the hospital. Notice of a pending accreditation must be posted in clear and conspicuous places throughout the hospital so that all medical staff, including house staff and other hospital employees, have an opportunity to request a meeting with the surveying staff. Notice of a pending accreditation survey must further be conveyed to the public through paid announcements in all newspapers of general circulation in the community and in any local newspapers whose predominant circulation is in the community served by the hospital.

4. Each hospital applying for accreditation must agree, as a condition of JCAH inspection, to display at each entrance a prominent notice that the hospital is JCAH approved or not approved. If the hospital failed accreditation, the notice must so state.

5. The interpretation section to Standard IV states that the governing body must 
establish guidelines for its relationship to the community. This standard must be expanded to include the requirement that $51 \%$ of the governing body of any publicly owned or voluntary hospital receiving tax exemptions must be members of the community served by the hospital.

6. There must be a formal mechanism for expression of and resolution of patient grievances within the hospital. The Commission must require that the hospital provide for patient ombudsmen or patient health advocates and provide an administrative hearing mechanism for the resolution of patient complaints concerning billing, quality of care or conditions under which care is rendered. The patient ombudsman must not be an employee of the hospital. The hospital may contract for the services of an ombudsman with a local welfare rights group, community action program, or other organizations based in the community served by the hospital. The number of such patient advocates or ombudsmen must be reasonably related to the patient population of the hospital.

7. All hospitals must declare responsibility for a defined population surrounding the institution as a condition of accreditation. This responsibility should include emergency ward, outpatient, ambulatory inpatient and preventive health services for the population defined. Determination of the population to be served must be made in cooperation with community organizations, health planning agencies, and municipal or county departments of health. Such a requirement should in no way result in exclusion of patients from outside the defined population for service, although in some cases it may limit the number of such outside patients that the hospital will be able to serve.

8. No medical staff privileges shall be denied on the basis of the applicant's attitudes toward, relation with, or employment by a prepaid group practice provider or by any other delivery mechanism providing physicians' and/or other medical services on other than a fee-for-service basis.

9. All financial records of all accredited institutions (voluntary, public or proprietary) must be regarded as matters of public record for review by the community and any other interested party. Minutes of Governing Board meetings, Medical Care Audit or Evaluation Committee meetings, and medical staff meetings must be made available for public inspection. All admission and collection policies shall be reduced to writing and made available to the public. Hospitals must prepare statistics comparing ward and private accommodations, including comparative statistics as to average patient stay, ratio of staff to patients, type of diagnosis, and number of laboratory tests performed on patients. Data must also be prepared relating to experimentation on patients in the hospital, indicating for each experiment, the kind of accommodations in which the patient is situated and his source of payment. All such data must be made available to the public.

Io. The last sentence in the second paragraph of the interpretation section to Standard V should be made mandatory so as to read: 
Plans to provide or expand a specific service must not be developed without a determination having been made that the proposed program meets a defined community need in a manner that comports with community views as to organization and delivery of medical services.

In addition, specific provision must be made for direct consultation with existing health planning agencies and community groups, for the purpose of ascertaining community need. The following language must be added to the paragraph:

In determining community needs, the governing body must consult with the duly constituted local or regional health planning council, and with groups representing the community the hospital serves.

II. No hospital shall be permitted to provide any different quantum or kind of services to a patient solely by reason of his source of payment. Medicaid and Medicare patients must be afforded private or semi-private accommodations if such are available. No patients may be assigned to ward accommodations on the basis of social, economic, religious, or racial status, where the patient has not requested such assignment.

I2. Hospitals must be required to include doctors who have no affiliation status, no proprietary or financial interest, and are not employees of the hospital on their utilization review and medical care evaluation and audit committees.

I3. Standard I of emergency services must be clarified so that it is clear that a patient will not be transferred or referred to another facility unless it is "medically indicated," without regard to ability to pay, race, creed, or national origin and only at such time as the patient's medical records are complete and up-to-date. No patient may be transferred until the receiving institution has consented to receipt of that patient.

I4. Laboratory services, not merely facilities, must be available within a time period reasonable for the type of test involved, considering the condition of a patient and the attending physician's judgment concerning the medical need for the test.

15. Emergency rooms and outpatient clinics, as well as inpatient facilities, must have proper facilities to insure the privacy of patients with regard to privacy of body and disclosures made during the course of examination. No examining facility should permit viewing of the patient's body other than by the examining doctor and his professional assistants, nor should the facility be situated so that any statements by the attending physician or patient can be overheard by other patients, passersby, or other hospital employees.

16. Officials of investigating agencies must not be permitted to interview patients in any hospital facilities except with the written consent of the attending physician based on his evaluation of the patient's condition and medical needs. No investigating officer may be permitted to be present during treatment or examination of the patient. 
I7. Hospitals must have adequate triage personnel to insure adequate, effective, and expeditious treatment of each applicant for services. All hospitals serving a substantial foreign speaking patient population or minority population shall be required to have triage nurses of that foreign speaking group or other minority group in their emergency room. If triage personnel are not available who speak the foreign language of any substantial segment of the patient population, the hospital must provide health aides who speak the language to work with triage personnel.

r8. The hospital must have an affirmative written policy of instructing all personnel to advise patients concerning what is happening to them, what is expected of them, and the nature of the medical tests performed on them.

19. No patient shall be operated upon by a resident or intern unless he is told beforehand that such resident or intern will have a role in the operation and consents to such surgical procedures in writing.

20. No patient shall be observed by students not directly participating in his treatment except with his written consent.

2I. Hospital rules and regulations shall clearly provide that there be no greater number of diagnostic tests performed on ward patients than are performed on patients in other accommodations in the hospital for the treatment or diagnosis of a particular condition. The status of ward patient shall not constitute a basis for any differential treatment with regard to number of diagnostic tests, $\mathrm{x}$-rays, or other laboratory procedures or examinations performed; nor shall it constitute a basis for any differential treatment with regard to the solicitation of consent for purposes of surgical procedures or experimentation.

22. No hospital shall refuse admission to Medicare or Medicaid patients where beds are available.

23. All hospitals must provide a reasonable quantum of free or below cost patient care.

24. No hospital with emergency facilities shall limit those facilities by informing emergency ambulance facilities in the community not to bring emergency patients to that hospital.

25. Inspection reports prepared by JCAH surveyors should be made available to any patient, community group served by the hospital, or staff of the hospital, which requests such a report. Where, under recommendation 3, a public hearing has been held or a meeting held with medical staff, employees of the hospital, and/or the community on matters pertaining to the accreditation, the surveyors' report must make explicit findings with regard to complaints and allegations made at such meetings or hearings.

26. Each hospital must have an adequate mechanism for patients to contact nursing personnel to come to their beds. All requests for attention from patients must be answered promptly. 


\section{APPENDIX B}

JCAH Certification Status of Hospitals Participating in Medicare, June 30, 9970

\begin{tabular}{|c|c|c|c|c|c|c|c|c|}
\hline & \multicolumn{2}{|c|}{ All Hospitals } & \multicolumn{2}{|c|}{$\begin{array}{l}\text { All Hospitals Other } \\
\text { Than TB or Psychiatric }\end{array}$} & \multicolumn{2}{|c|}{ TB Hospitals } & \multicolumn{2}{|c|}{ Paychintrio Hospitals } \\
\hline & Hospitals & Beds & Hospitals & Beds & Hospitals & Beds & Hospitals & Beds \\
\hline TOTAL.................... & 6,799 & $1,209,791$ & 6,354 & 857,949 & 105 & 21,712 & 340 & 330,130 \\
\hline $\begin{array}{l}\text { HospiTaus CERTIPIED A...... } \\
\text { (in substantial compliance } \\
\text { Hith no significant } \\
\text { deficiencies) }\end{array}$ & 4,684 & $1,005,499$ & 4,384 & 745,015 & 80 & 18,821 & 220 & 240,703 \\
\hline $\begin{array}{l}\text { HosPITALS CERTTPIED B*.... } \\
\text { (in substantial compliance } \\
\text { tith deficiencies) }\end{array}$ & 1,704 & 190,916 & 1,560 & 98,698 & 24 & 2,851 & 120 & 80,307 \\
\hline $\begin{array}{l}\text { Hospirsus CEzTTHIFd C..... } \\
\text { (special or "sccess" } \\
\text { certification as explained } \\
\text { in 20 C.F.R. } 8405.1010 \text { ) }\end{array}$ & 411 & 13,376 & 410 & 13,336 & 1 & 40 & Nono & Nono \\
\hline
\end{tabular}

* No data available as to number of hospitals deficient in six or more Conditions of Participation.

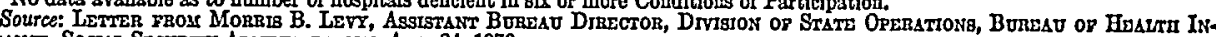
BURance, Soctal Security AdMTISTRatioN, AUG. 24, 1970. 
APPENDIX C

Number of JCAH-Accredited and Nonaccredited Hospitals and Beds, By State

\begin{tabular}{|c|c|c|c|c|}
\hline \multirow[b]{2}{*}{ Jurisdiction } & \multicolumn{2}{|c|}{ JCAH-Accredited } & \multicolumn{2}{|c|}{ Nonaccredited by JCAH } \\
\hline & No. & Beds & No. & Beds \\
\hline 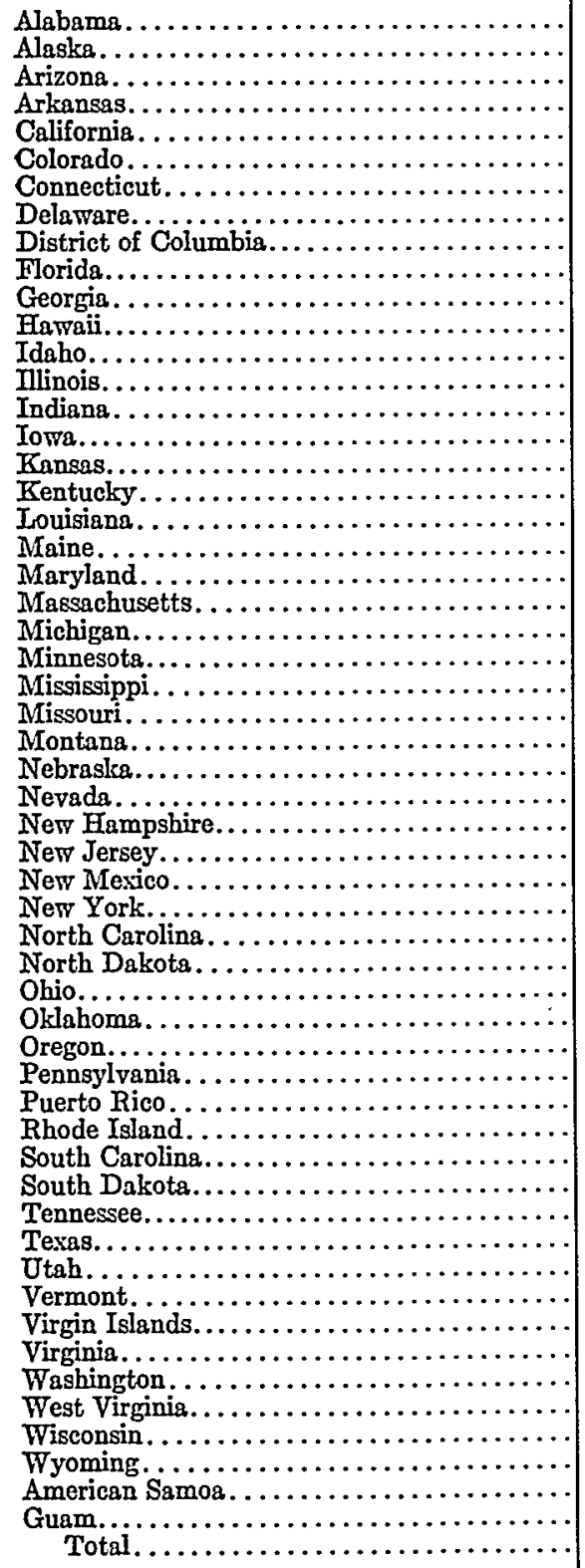 & $\begin{array}{r}54 \\
3 \\
33 \\
44 \\
385 \\
50 \\
49 \\
9 \\
13 \\
106 \\
69 \\
15 \\
19 \\
246 \\
79 \\
68 \\
61 \\
70 \\
54 \\
42 \\
44 \\
155 \\
209 \\
105 \\
30 \\
86 \\
23 \\
46 \\
8 \\
28 \\
103 \\
24 \\
366 \\
99 \\
24 \\
194 \\
57 \\
57 \\
237 \\
26 \\
18 \\
42 \\
18 \\
73 \\
191 \\
12 \\
17 \\
1 \\
84 \\
74 \\
46 \\
121 \\
11 \\
0 \\
132 \\
132\end{array}$ & $\begin{array}{r}9,418 \\
252 \\
6,090 \\
6,504 \\
85,918 \\
10,324 \\
18,751 \\
2,942 \\
11,080 \\
23,883 \\
11,917 \\
2,858 \\
1,667 \\
43,498 \\
20,268 \\
11,703 \\
9,187 \\
10,372 \\
11,698 \\
4,088 \\
18,633 \\
36,990 \\
47,292 \\
20,930 \\
4,585 \\
22,266 \\
2,534 \\
5,946 \\
1,539 \\
5,030 \\
39,637 \\
2,449 \\
160,374 \\
15,690 \\
3,981 \\
44,682 \\
9,075 \\
8,265 \\
63,277 \\
6,246 \\
4,952 \\
10,712 \\
2,228 \\
14,181 \\
37,645 \\
2,583 \\
3,639 \\
109 \\
15,719 \\
12,625 \\
7,057 \\
21,363 \\
910 \\
0 \\
945 \\
945,664 \\
\end{array}$ & $\begin{array}{r}67 \\
18 \\
21 \\
57 \\
196 \\
40 \\
2 \\
0 \\
2 \\
95 \\
66 \\
9 \\
28 \\
50 \\
55 \\
80 \\
101 \\
59 \\
72 \\
18 \\
17 \\
35 \\
57 \\
88 \\
66 \\
84 \\
40 \\
66 \\
12 \\
7 \\
17 \\
17 \\
34 \\
50 \\
37 \\
62 \\
78 \\
35 \\
54 \\
75 \\
3 \\
34 \\
44 \\
44 \\
78 \\
307 \\
4 \\
6 \\
4 \\
34 \\
49 \\
36 \\
62 \\
18 \\
1 \\
\end{array}$ & $\begin{array}{r}3,437 \\
678 \\
1,110 \\
3,349 \\
9,748 \\
1,746 \\
146 \\
0 \\
542 \\
11,474 \\
4,562 \\
449 \\
846 \\
29,784 \\
6,222 \\
5,141 \\
5,657 \\
7,513 \\
4,568 \\
683 \\
4,134 \\
5,092 \\
12,123 \\
3,914 \\
3,188 \\
8,015 \\
1,136 \\
4,034 \\
815 \\
269 \\
2,170 \\
676 \\
3,685 \\
12,704 \\
1,188 \\
5,276 \\
4,315 \\
2,000 \\
16,911 \\
3,432 \\
2,198 \\
4,563 \\
1,402 \\
3,891 \\
17,692 \\
920 \\
184 \\
97 \\
4,223 \\
2,164 \\
1,717 \\
3,583 \\
1,171 \\
145 \\
0 \\
246,682 \\
\end{array}$ \\
\hline
\end{tabular}

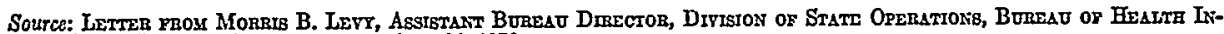
soRANCE, SOCLAT SECURITY ADMTISTRATION, AUa. 24, 1970. 